\title{
Islamic Immaterial Culture and Ethnopolitical Symbols in Georgia and the Russian Federation
}

\author{
Babak Rezvani
}

\begin{abstract}
This article discusses the ethno-political and immaterial cultural representations of Russia's and Georgia's Muslim minorities as reflected in their anthroponyms, toponyms, flags and coats of arms. It is obvious that Such representations reflect cultural expressions, as they may depict ethnic or religious symbols. Both Russia's and Georgia's attitudes towards Islamic cultural expressions are rather liberal. Symbols and names tell a lot about a people's cultural freedom and orientation. However, it appears from research that religious practice and freedom do not necessarily correlate perfectly with representation of symbols. In accordance with the legacy of the Soviet nationalities policy, by which certain ethnic groups were afforded privileges in an autonomous region, the current representations of immaterial culture and ethno-political culture seem to have a territorial rationale.
\end{abstract}

Keywords: anthroponyms, Bashkortostan, the Caucasus, ethnopolitical symbols, Georgia, nation building, onomastics, Russia, Tatarstan, toponyms

Toponyms, anthroponyms and ethno-national flags and coats of arms are social representations of cultures, as they are often carried by large segments of the population. The latter two may be called political representations of culture, as they are often politically regulated by laws. Although onomastics, i.e. the study of names, is traditionally studied within humanities, particularly by linguists, it is also related to social sciences, particularly to those disciplines and fields that apply qualitative social research usually with empirical and explorative characters. ${ }^{1}$ In the Oxford Handbook of Names and Naming (Hough and Izdebska 2016), several chapters are included that discuss the relation between onomastics and psychology, society (Ainiala 2016: 371-381), ethnonyms (Koopman 2016: 251-262), identity (Aldrin 2016: 382-394) and, 
notably, religion (Muhr 2016: 385-602), geography (Gammeltoft 2016: 502513) and anthropology (Bramwell: 263-278).

It is not very far-fetched to imagine the relevance of ethnicity and cultural factors to social sciences and particularly to anthropology and geography (see e.g. Bassin 2009; Gogsadze 2019; Ilyasov 2018; Kaplan 2019; Rezvani 2013b; Rezvani 2019a; Rezvani and Gonzales 2018; Rezvani and Ilyasov 2017; Shahshahani 2019; Shoeibi 2019). Friedrich Ratzel (1844-1904), a German geographer, has two major works that may be worth mentioning in this regard: Völkerkunde - which could be translated as knowledge about peoples, or perhaps even nationology - and Anthropogeografie. It appears that this latter term was coined by L.F. Kämtz in 1842 and established later by Ratzel (Heucke 2006; see also Penk 1912). Ratzel's conception of the relation between peoples and geography is very often different from the current perspectives within human geography and anthropology, and certainly many of his statements cannot be confirmed. Still, his choice for the titles of these works, as well as the name of the subdiscipline 'political anthropology', indicate certain academic antiquity of the relation between peoples, their cultures and their political environments.

The study of names, i.e. onomastics, has traditionally been studied within linguistics and history. It tried to give etymologies for names using linguistic or historic methods. It was also used to explore and map names, and their origins, within a territory and among ethnic or national groups. The study of flags and coats of arms, i.e. vexillology, is traditionally similarly approached within humanities with similar scopes. In the modern social sciences, however, particularly in anthropology and political and cultural geography, explorative and often descriptive, rather than explanative, approaches of social research are appropriate. Primarily, researchers can explore anthroponyms, toponyms and flags and coats of arms and then find out their origins. By exploring patterns, researchers can formulate hypotheses and make even some conclusions. In social sciences, it is not necessary to apply linguistic methods. However, ethnolinguistic data as well as other data collected, particularly by fieldwork, are useful, as they often corroborate conclusions reached by other data and help understand those materials better. In this article, primarily an explorative-descriptive approach is taken. First, I explore the anthroponyms, toponyms, coats of arms and flags, and if possible other expressions of culture that can enhance the understanding of the former, and then we try to find patterns and reach certain conclusions. Although etymologies of certain names are explored, this is not the primary scope of this article. Moreover, as this article can be regarded as a first stage of a series of (ongoing) studies, the assistance of experts from other disciplines, particularly linguistics, history and philology are welcome, for the purpose of etymology of names and historical development of names and symbols in a region and among ethnic and national groups.

In this article, I share some results of my ongoing research project about ethnogeopolitics of immaterial culture and symbols. ${ }^{2}$ This project partly covers 
cultural and political onomastics, as it investigates names, i.e. anthroponyms and toponyms, in addition to political symbols such as flags and coats of arms. This article's focus of study are Muslim peoples and regions of Russia and Georgia. However, in order to put the results in a wider context and offer comparisons, sometimes other peoples and regions are discussed. Such immaterial cultural (anthroponyms and toponyms) or visual (flags and coats of arms) representations could reflect cultural expressions and orientations, as they may depict ethnically or religiously meaningful symbols. ${ }^{3}$

In order to collect data about names, in all cases I have done several unstructured interviews. In Georgia I have also collected material in the field. In the case of Tatars, in addition to these interviews, I rely on the study by Edwin Lawson and colleagues (2014), and in the case of North Caucasians, in addition to these interviews, I rely on internet websites and information offered by experts. As the study by Lawson and colleagues is a rare case of a systematic study about this matter, I will discuss that work and its main conclusions in this article. I have been collecting materials for two decades, but for this article I rely on material collected from 2014 to 2019. Flags and coats of arms are often visible in the regions (i.e. in fields) and are depicted in a number of authoritative websites.

\section{The Russian Federation: Anthroponyms and Toponyms}

Onomastics is the study of names; of anthroponyms, i.e. personal names, ethnonyms, i.e. names of ethnic groups, and toponyms, i.e. names of geographical places. As mentioned above, such studies are ethnologically, and generally socially, relevant, as they reflect a region's and its people's social, cultural and political orientation and (re)presentation (see e.g. Berg and Vuolteenaho 2009). Studies about onomastics have not been rare in the disciplines of humanities. Although social scientific and interdisciplinary approaches of onomastics, discussing its social and political relevance, were rarer, they are also emerging. ${ }^{4}$ In this article I use data collected during my fieldwork in addition to data collected off the field, from written digital and printed sources and (remote) interviews.

There are a few websites that list the personal names prevalent among a few Muslim ethnic groups in Russia. These lists claim to offer a list of names used by the Vainakh, i.e. Chechens and Ingush, and Circassians, i.e. the Adygheans, Kabardians and Cherkess or, (mostly Besleney) Circassians. ${ }^{5}$ Although the list of Circassian names in the websites tend to list the secular purist (i.e. of pure Circassian origin) Circassian names, in practice the Circassian names, similar to those of other North Caucasians, tend to be more religiously motivated names, often derived from Arabic.

The Soviet Union is often called a prison of peoples. However, it activated a certain type of ethnonationalism (Martin 2001; Nalbandov 2016: 188-190; 
Rezvani 2013: 69-71; Rezvani 2015: 60-77; Slezkine 1994; Suny 1998). Religion was not prohibited but controlled by the state. A similar situation, but of a less restrictive nature, prevails in post-Soviet Russia. There are many mosques and Islamic schools in Russia. The most northernly situated mosque in the world is in Russia. As Simona Merati (2017: 128, 141-142) maintains, Islam, other than extremist non-indigenous types of Islam often collectively branded as Wahhabism, is tolerated in Russia. As the review of names of Muslim ethnic groups in Russia reveals, Muslims are free to choose any Islamic names they wish. Nevertheless, there have not been many studies in English with an eye on regional differentiation. ${ }^{6}$

It should be noted that it is difficult and to a certain extent arbitrary to define what is a Muslim name. Are these only the names mentioned in the Koran and other names known from Islamic historical scriptures, or could they be all names used by ethnic and national groups that confess Islam? Both definitions could be true. This article concentrates on names used by Muslims of Russia, which are derived from different linguistic elements. ${ }^{7}$

Such personal names (anthroponyms) are mainly based on Arabic names, often after historical personalities in Islam or names mentioned in the Koran. However, a good share of them have Iranian, Turkic or Caucasian origins. Moreover, there are names constructed from a combination of these linguistic elements. Many Muslims in Russia may also choose Slavic personal names as their official name or as a second, informal name or nickname. Similarly, there are different definitions possible for Islamic toponyms. This article has looked for the presence of toponyms as namesakes of major important places of the religion of Islam, notably, Mecca and Medina. Islamic toponyms may also be defined as names having an Islamic theme such as Masjid (mosque) or Mashhad (martyrium). ${ }^{8}$ Using toponymical registers in Russia or GIS applications are good strategies to investigate toponyms. ${ }^{9}$ There are also governmental and several other websites that could be used for an impression of the prevailing names of officials and ordinary persons in those territories, as well as for visual flags and coats of arms. Most notably, ethnographic field research is an important strategy in research such as this. ${ }^{10}$

Tatars as the largest Muslim ethnic group in Russia, have attracted relatively more attention from scholars than other Muslim ethnic groups in Russia, and there is even written material on Tatar onomastics in English. Tatars live in the heartland of Russia, in both European and Asian parts of Central Russia, relatively far away from Central Asia and the Caucasus. Tatars speak a Kipchak Turkic language. Similar to Muslims of South Asia, Turkey, the Balkans, Afghanistan and Central Asia, and similar to their ethnic neighbours, the Bashkorts (also called Bashkirs), Tatars are Hanefi Sunni Muslims. The Muslims in the other traditionally Muslim region of Russia, the North Caucasus, are divided between the Shafe'i and Hanefi branches of Sunni Islam, even though the majority of them belong to the former branch. Circassians of the North Caucasus are Hanefi Muslims. However, most other Muslims in the 
North Caucasus, i.e. most Ingush and Chechens, and the majority of Muslims in Dagestan, are Shafe'i Sunni Muslims and have Sufi traditions. In addition, a significant Twelver Shia population resides in southern Dagestan, in and around the city of Derbent (Darband). ${ }^{11}$

Despite the fact that knowledge about Tatarstan is scarce in Iran, Turkey and Afghanistan (and other Islamic countries outside the post-Soviet space), Tatarstan could be regarded as belonging to the Turco-Persian (also called Persianate) civilisation or cultural domain. Not only the Tatar immaterial culture but also their material culture, particularly architecture, reveals relations with the aforementioned cultural domain, particularly with Central Asia. In contrast to Muslim names in Africa, which are predominantly derived solely from Arabic (Zwawi 1998), Tatar names often also have Persian and Turkic elements in them, which reveals the Tatar history of Islamisation by proselytism first from Baghdad and later from Central Asia and particularly from Khorezmia (Xorazm/Xwârazm). In contrast to much of Central Asia and the Caucasus, which were incorporated into Russia relatively late in the nineteenth century, Tatarstan and its vicinities inhabited by Tatars were incorporated into Russia in the sixteenth century (Merati 2017: 7).

The aforementioned list of names, listed in diverse websites and books and similar sources, are indeed useful sources of information. However, the study by Lawson and colleagues, entitled Tatar First Names from West Siberia: An English and Russian Dictionary (2014), is built upon systematic research and therefore, deserves more lengthy discussion. The authors' survey is commendable, as it does not include only a reproduction of aggregated data and statistics, but also provides information about the respondents by questioning and interviewing them. The etymological dictionary of Tatar names, the second part of the book, is indeed a piece of fine art. Only people knowledgeable about Tatars in the western Siberia and Volga regions could be able to collect such data and write such a dictionary. This etymological dictionary is clearly an evidence of the authors' superior command of Arabic, Turkic and Persian.

The authors of this book report the results of an onomastic study about Tatar first names in western Siberia. Accordingly, two research questions guided their study: (1) Is there a general pattern of linguistic Russification of the indigenous Tatars in western Siberia? (2) Is there a significantly larger extent of linguistic Russification among the indigenous Tatars who became urbanised in comparison with those who remained in the villages? Both questions were answered positively. The second part of the book contains an etymological list of names, and the first part reports the conclusion of a survey of 799 Tatars, half of whom were urban and half rural, and with sufficient variety in the gender, age and occupation of respondents. Their focus of study was the community of Tatars in the western Siberian city of Tomsk and villages in its vicinity, about 20,000 in total. The selection of this community was appropriate for the purposes of this study. Tatars are a relatively small minority there and live among a large majority of Russians. Therefore, it could plausibly be tested 
if Russification had an impact on them. Although the authors call this an onomastic study, the first part of this book could best be typified as an ethnological study. The authors were guided by initial questions and undertook a survey among a number of Tatars. As they were familiar with the culture of Tatars, they tried to test hypotheses and by that could explore other questions in the course of the research.

The results of this survey were generally evident and not surprising: for example, the extent of linguistic Russification was larger among the young and urban population than it was among the older and rural population. The Russification was also reflected in their first names. However, it also contained interesting and to some extent surprising results: it appeared that twice as many women had both a Russian and a Tatar name than men. This is in contrast to the general patterns that display a larger degree of cultural accommodation, or even assimilation, among men than women. It appeared also that the Russian and Tatar personal names, of the same persons, began with the same letter and often even had the same number of syllables, e.g. Malik $\rightarrow$ Mikhail, Nadiya $\rightarrow$ Nadezhda.

The second part of the book is very interesting. It is a pure onomastic study that offers etymological explanations for the Tatar names. Having reviewed the Tatar first names, the authors distinguish three chronological categories of Tatar first names: the old ones, the newer ones and the newest ones. The old Tatar names are primarily of Arabic origin, and sometimes are combinations of Arabic, Persian and Turkic. These names are religious names, many of which end with -ulla (from Arabic Allah), which in these combinations could best be translated as something belonging to Allah; for example, Nurulla (i.e. Nur-Allah) means the light of Allah. The newer names are often single words or combinations of Arabic, Persian and Turkic words, often in this order. These names are not religious words of the same type. Nevertheless, the abundance of Arabic and Persian in them indicates the Islamic and perhaps even Persianate (also called Turco-Persian) civilisational orientation of Tatars. Finally, the newest first names may still bear Arabic, Persian or Turkic elements, but they increasingly contain Russian and even European elements. To these names belong also compound names with a Soviet ideological background. One such name is Marlen, which is constructed from Marx and Lenin. The latter phenomenon is also observable among other (post-)Soviet peoples.

In the list of the Tatar names, the authors provide etymological explanations, both in English and in Russian. ${ }^{12}$ However, the terminology used in Russian is different from that used in English. For example, the Russian etymological dictionary attributes the Iranian words in Tatar first names to 'Персидский' (Persidskiy = Persian), i.e. the Persian language as one of the Iranian languages, whereas the English etymological dictionary attributes them to 'Iranian', i.e. the Iranian languages, a branch of the Indo-European languages that also includes the Persian language. Similarly, the research in the first part of the book speaks of 'Turkish' names, while the etymological 
list speaks of 'Turkic'. Regarding the fact that the Turkic language that forms the basis of Tatar is Kipchak Turkic and different from Anatolian or Ottoman Turkish, the designation 'Turkic' rather than 'Turkish' is correct. However, the designations 'Persian' and 'Iranian' both could be correctly used, as Persian is a language belonging to the Iranian family of Indo-European languages. Persian, as a literary language par excellence, has influenced many other languages. In the case of Tatar, most influences from the Iranian languages have been from Persian rather than from any other Iranian languages. ${ }^{13}$

In comparison, the Muslim names in the North Caucasus are mainly derived from Arabic and are often based on the Koran or other Islamic scriptures, and to a lesser extent from the indigenous Caucasian, Turkic and Iranian languages. Among popular indigenous Caucasian names are, for example, Malkhaz and Anzor. Elements from Turkic, e.g. Bek or Beg - probably from the Iranian origin of Bag or Bagh meaning 'lord', cf. Russian Bog - could often be attached to such names. Also, names of Turkic origins do exist, e.g. Tengiz (sea or lake) or Tamerlan - a local derivation of Amir Timur, a Central Asian emperor who also conquered Persia and the Caucasus. Tengiz sounds similar to Genghis (Chengiz) Khan. Temuri (from Timur) and Tengiz also exist among Georgians. ${ }^{14}$ The existence of such anthroponyms as Tengiz and Tamerlan among Caucasians could be explained by their reverence for strong leaders and warriors, despite the fact that the official local historiographies do not always reserve a positive role for these persons. ${ }^{15}$ Pure (i.e. noncombined) Iranian personal names are rather scarce in the North Caucasus, in contrast to the South Caucasus and southern parts of Central Asia. For example, Iranian personal names, often Persian and sometimes Parthian, are prevalent in the South Caucasus and Central Asia, particularly in the republics of Azerbaijan (e.g. Novruz, or Novruzali, Farhad, Nazpari, Nargul, Bahram, Bahruz and Shirin) and in Uzbekistan and Tajikistan (e.g. Farhod, Jamshed, Gulnora). Iranian personal names exist also to some extent among Armenians (e.g. Ardashes, Anahid, Arshak) and to a larger extent among Georgians (e.g. Rostom, Zurab, Rotam, Nestan, Giuli, Tamaz, Darejan, Nodar, Bezhan, Givi). ${ }^{16}$ However, anthroponyms of Persian origin are rare in the North Caucasus, other than in southern Dagestan. ${ }^{17}$ A notable exception could be the name Rustam, a legendary hero from the Shahnameh epic poem by Ferdowsi, which is prevalent in the North Caucasus and also in the Volga region among Muslim ethnic groups. Also, this fact may be an indication for the North Caucasian reverence for strong historical figures. Also, Russian names such as Marat and Ruslan are increasingly used among Muslims of Russia in the Volga region and the North Caucasus.

Using toponyms as anthroponyms is also prevalent in the North Caucasus; notably, in parts of Dagestan, Ingushetia and Chechnya, the female names Makka and Madina are used after the Muslim holy cities of Mecca and Medina. There are no toponyms of major settlements that have an Islamic theme, such as Masjid (mosque) or Mashhad (martyrium).${ }^{18}$ However, there is a settlement 
in Dagestan called Maka. Further research is needed to determine whether it is a namesake of Mecca or has other etymological or semantic origins.

\section{The Russian Federation: Flags and Coats of Arms}

After the collapse of the Soviet Union, the newly independent republics chose to reinstate (a version of) of their older flags, or new flags were designed in order to replace the communist ones. These flags often displayed symbols and cultural elements from the titular people - i.e. the ethnic groups after whom a territory is named and who are often the majority in that territory. With the minor exception of Moldova, none of the eight union republics, or better said, Soviet successor states with a Christian majority adopted a flag that symbolised Christianity, immediately after the collapse of the Soviet Union. Currently, only Georgia has a prominent and typical Christian flag. After the Rose Revolution, Georgia replaced its previous post-independence flag with a new one with five crosses. Four out of the six Muslim former union republics chose flags with the colour green - a symbolic colour in the Islamic world - in them, and in three of these flags the Muslim symbol of a crescent is illustrated. Kyrgyzstan and Kazakhstan are the only two former Soviet republics in which no Islamic symbols or the colour green is present. Remarkably, these are also the post-Soviet states that have retained Russian as a an official national language, whereas in the other states predominantly inhabited by Muslims, the status of Russian was decreased to the level of interethnic language of communication and the Muslim majority's language was declared as the sole official state language.

All Russian federal subjects, i.e. regions, have their own flags. In the flags of several regions with a Christian population a cross is depicted. ${ }^{19}$ A Muslim Turkic, and to a certain extent separatist, movement in the Volga-Ural region uses a flag in green and red with a crescent and star. This movement, which enjoys no significant number of supporters, wants to establish a country that would encompass the Muslim-inhabited republics of Tatarstan, Bashkortostan and their vicinities, which they call the Idel-Ural state (Figure 1). Idel is the Tatar name for the river Volga (Cf. Atel, Etel or Itil in Persian, Turkic and Arabic historical sources $=$ اتل or (آتل $).{ }^{20}$ Also other unofficial flags used mostly by ethnic enthusiasts may exist in which crescent or other ethnoreligious Islamic elements may appear. However such flags are not official and do not belong to the recognized Russian administrative territorial autonomies. The very typical Islamic symbol of a crescent does not appear in any official flags of autonomous territorial federal subjects of the Russian Federation. However, it is important to note that all autonomous federal subjects of the Russian Federation, with traditionally a Muslim majority, have a flag that contains the colour green. In that sense, these flags could be associated with their Islamic heritage, even if the choice of the colour may or may not have been intentional. 


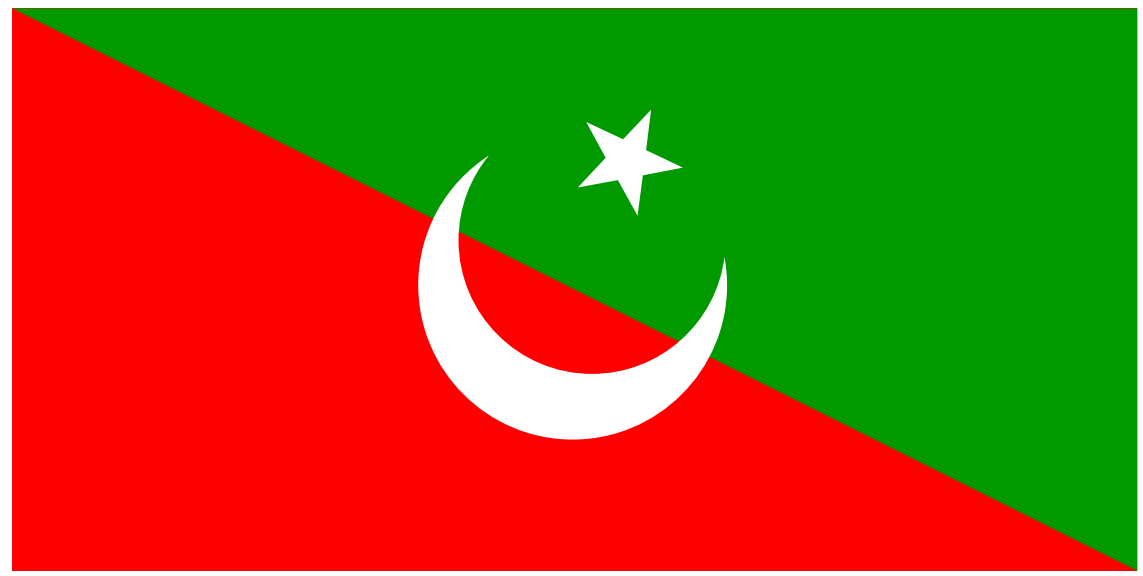

Figure 1: Idel-Ural (separatist) flag. Source: https://www.crwflags.com/fotw/images/r/ ru-idur.gif.

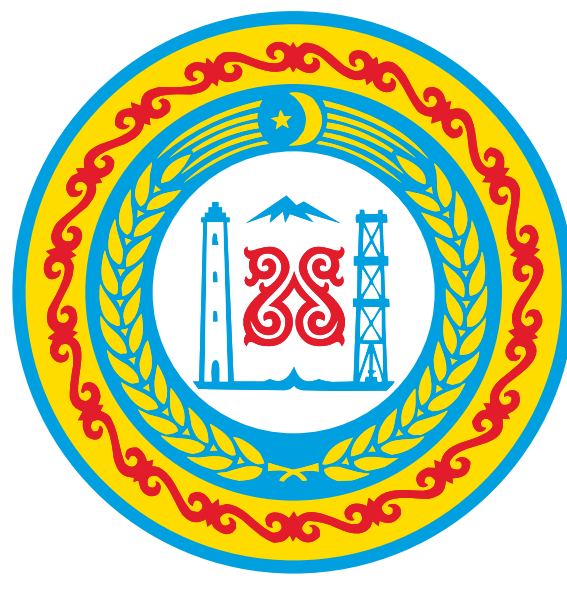

Figure 2: Chechnya's coat of arms.

Source: https://commons.wikimedia.org/ wiki/Чечня\#/media/File:Coat_of_arms_ of_Chechnya.svg.

These flags often also depict elements from the landscape, traditional floral motifs or other ethnic symbols. Also, all autonomous republics with a Muslim majority have coats of arms in which the colour green is present. The only exception is the Chechen coat of arms, which has no green in it but does have a crescent (Figure 2). For example, the flag of Adyghea depicts the Circassian ethnonational symbol on a green background (Figure 3). Adyghea is named after the Muslim Adyghe Circassian people. However, the majority of the population in that territory is now composed of Russians and other Christian ethnic groups. Also, the Buddhist autonomous regions of Russia, Kalmykia and Buryatia, have Buddhist symbols in them (see Figure 4). On the other hand, North Ossetia-Alania, the only Christian autonomous region in the North Caucasus, has adopted a flag without any Christian symbolism. 


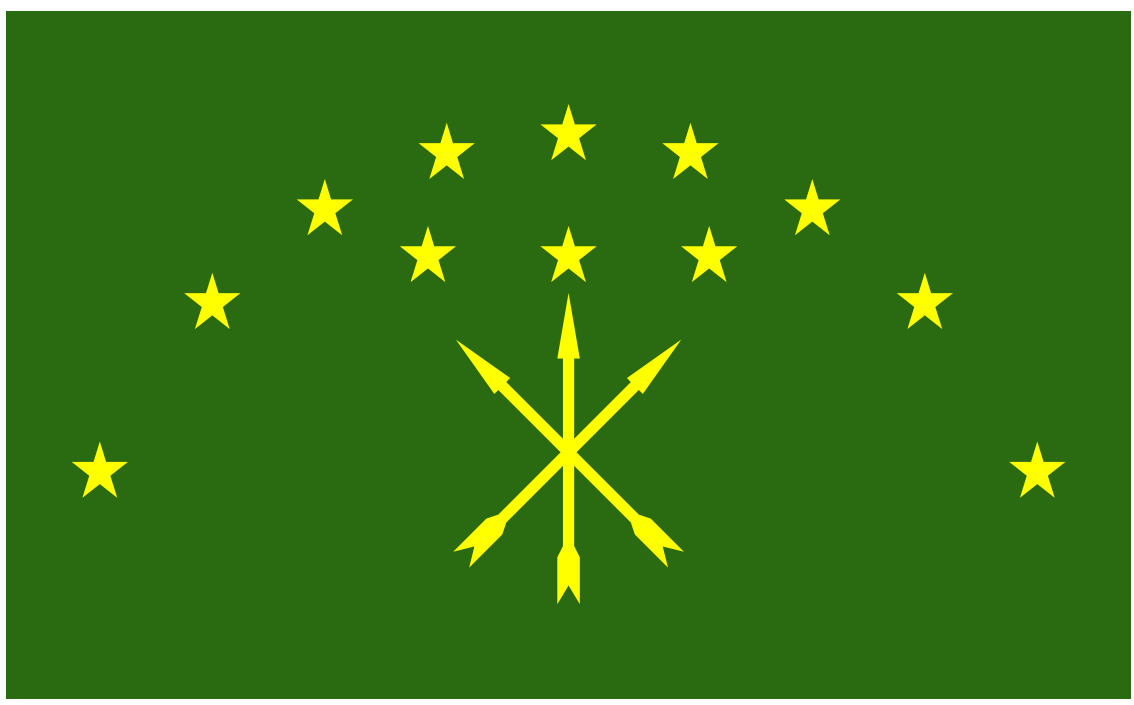

Figure 3: Flag of Adyghea. Source: https://www.crwflags.com/FOTW/images/r/ru-01.gif.

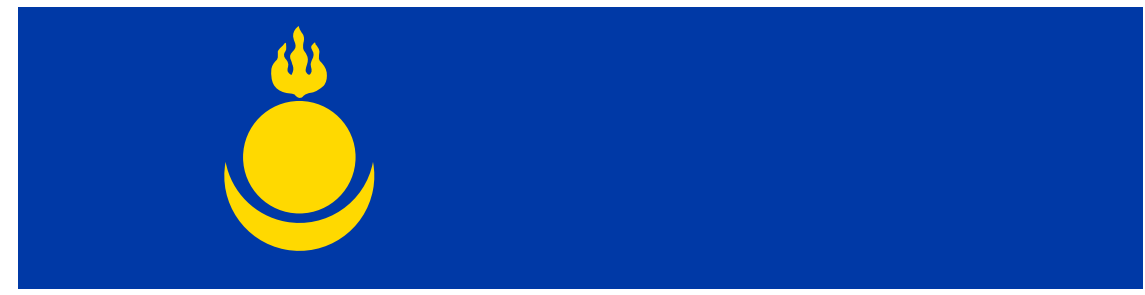

Figure 4: Flag of Buriatia. Source: https://www.crwflags.com/FOTW/images/r/ru-bu.gif.

\section{Georgia: Anthroponyms and Toponyms}

Muslims of Georgia are concentrated in Adjara, the southern part of Kvemo Kartli (also known as Saborchalo), and Pankisi Gorge. There is also a significant Azerbaijani-speaking Shia Muslim population in Tbilisi, the capital city of Georgia. Kistis, i.e. the Chechen citizens of Georgia, live in a few villages in the Pankisi Gorge. Their first names do not differ much from those in Chechnya. However, their family names usually end with the Georgian -shvili or -dze instead of -ov. 
Traditionally, Georgian-speaking Sunni Muslims lived in Adjara. However, after independence many have converted to Orthodox Christianity. Still, Sunni Islam is practiced by the majority, or at least by a significant part, of the population in Upper Adjara, and also elsewhere in Adjara among the elderly. Previously Islamic personal names such as Memed (i.e. Mohammed) were prevalent among Adjarans. These days, however, such names are rare. Today the naming behaviour in Adjara differs only slightly from the rest of Georgia. Adjarans choose Georgian names. Similar to Christian Georgians, they may also choose the earlier-mentioned old Iranian names, often from heroic figures from the Shahnameh epic poem by Ferdowsi. However, such names cannot be designated as Islamic names. However, names such as Aslan, meaning 'lion' in Turkic, and secular Georgian names such as Shota and Lasha are proportionally more prevalent among the names they choose.

The Shia Muslim Borchali people, also known as the Azerbaijanis of Georgia, live in the southern part of Kvemo Kartli - colloquially called Saborchalo, i.e. the land of Borchalis. They constitute the majority of the population in the districts of Dmanisi, Bolnisi and Marneuli. ${ }^{21}$ The choice for ethnonyms (Azerbaijani, or Borchali) is not a contested political issue among them as it was among the Êzidîs (Êzidî/Yezidi, or Kurd), who usually, particularly in Armenia and to some extent also in Georgia, preferred the ethnonym Yezidi above Kurd. However, the Borchalis constitute the urban majority only in the town of Marneuli, and the rest are settled predominantly in the rural areas of southern parts of the Kvemo Kartli region. They choose similar personal names as people in the Republic of Azerbaijan and Iran. Georgia has a rather liberal attitude towards its religious minorities' practices. Unlike in many postSoviet Muslim republics, the Islamic headdress, the hijab, is not frowned upon or stigmatised by the secular authorities. Owing to the tolerant and liberal attitude of Georgian authorities, the Shia traditional religious practices among the Borchalis are more similar to the practices in Iran than those practices in the Republic of Azerbaijan, where conform to the Soviet tradition the authorities regulate to some extent the religious and cultural lives.

Azerbaijanis of Tbilisi often trace their roots back to Iran. A majority of them trace their roots to migrants that arrived in the past centuries from Tabriz and other Iranian Azerbaijani cities. However, there are also traditional family names among them, such as Isfahani, that reveal a more central Iranian origin. The vernacular Azerbaijani language, particularly in Tbilisi, differs partially from the Azerbaijani language in the Republic of Azerbaijan. As they have been often enrolled in Russian schools, their vernacular is often void of neologisms and the language reforms of the Republic of Azerbaijan and have preserved some grammatical and lexical aspects of classical Azerbaijani Turkic, which also still exist in the Azerbaijani language spoken in Iran. Their vernacular contains Russian and Georgian vocabulary as well. Owing to daily interaction with Georgians, and with Turkish and Iranian tourists, their vernacular has even adopted some neologisms from Georgian, Turkish and Persian. 


\section{Georgia: Flags and Coats of Arms}

Unlike the Russian ones, the Georgian regular regions, dbs๓göo (mkharebi) (singular, dbsmo, mkhare) have no flags. All districts (rayons), however, have flags. Only the autonomous region of Adjara has a flag.22 The flag of Adjara depicts no Islamic symbols. It consists of the projection of the Georgian flag, with its Christian symbols, on the upper corner of a Greek-like blue-striped background (Figure 5). Also, prior to the Rose Revolution, the Adjaran flag did not have any Islamic symbols; it was a dark blue flag with seven stars representing the seven districts of Adjara (Figure 6). The Adjaran coat of arms does not display any Islamic symbols or the green colour either. However, in the flags and coats of arms of all Adjaran districts' flags, except that of the city of Batumi, the regional capital of Adjara, green is present - even in Kobuleti, most likely with a rather larger Christian majority - and yet at the same time most of them display stylised crosses. ${ }^{23}$ In the flags of Dmanisi, Bolnisi and Marneuli districts, in the Kvemo Kartli region, populated by Shia Muslims, no green or other Islamic symbols are present. In the first two districts' flags and all three districts' coats of arms stylised crosses are present. There is also a cross depicted in Marneuli's flag.

It appears, therefore, that the ethnoreligious symbolism of this area reflects the political reality rather than the cultural reality of the majority of its current inhabitants. Despite the fact that the attitude towards religion and religious minorities is liberal in Georgia, the whole territory of Georgia as a country,
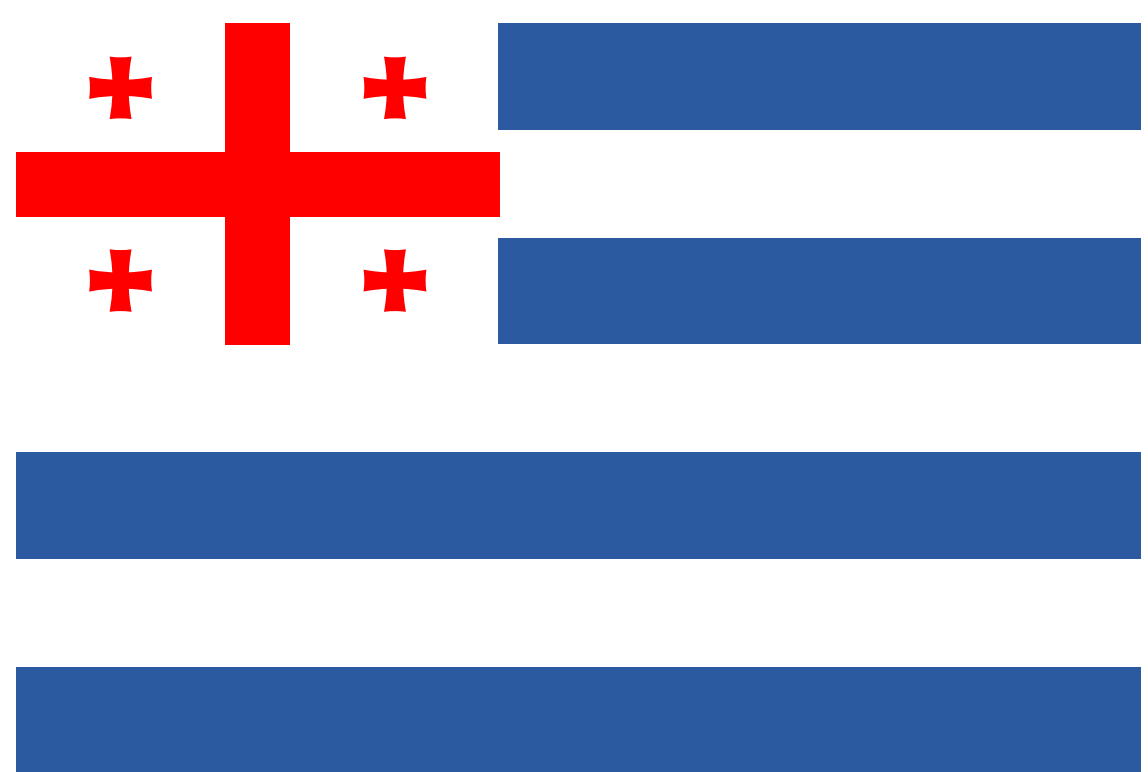

Figure 5: Flag of Adjara. Source: https://www.crwflags.com/FOTW/images/g/ge-ad.gif. 


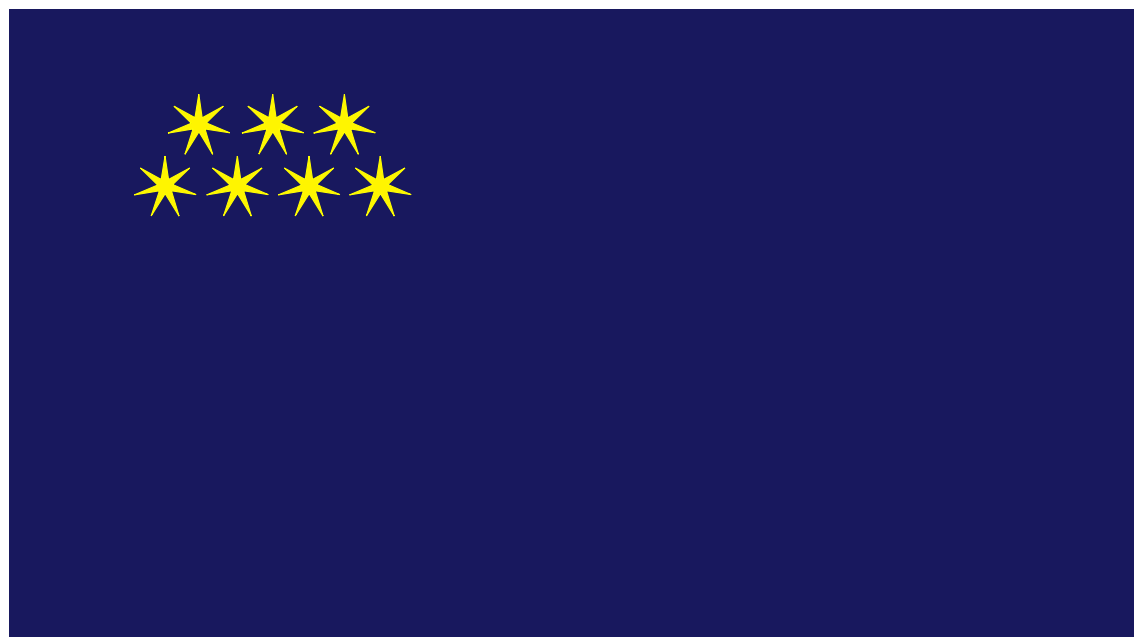

Figure 6: Old flag of Adjara. Source: https://www.crwflags.com/FOTW/images/g/ ge_ad20.gif.

and Georgians as a nation, are associated with Orthodox Christianity. In Russia, in the autonomous regions inhabited by Muslim religious minorities, however, Muslims are present among, and often predominate within, the local political, social and cultural elites. Russia as a large country adheres to certain degree of multiculturalism, which is reflected in the flags and coats of arms of regions inhabited by ethnic and ethnoreligious minorities.

\section{Final Remarks and Discussion}

In the Soviet Union religion was not prohibited but controlled by the state, and a similar situation, but of a less restrictive nature, prevails in post-Soviet Russia. A similar situation prevails also in Georgia. Symbols and names tell a lot about a people's cultural freedom and orientation. However, religious practice and freedom do not necessarily correlate with representations in symbols, as these are often affected by conscious political choices. Nevertheless, one can cautiously conclude that in the dominant Georgian symbolic nationbuilding process and discourse, the minorities are forgotten or neglected. Although religious minorities are free in their conduct, the Georgian state represents itself as a Georgian Orthodox Christian state. The fact that the Georgian Orthodox Church has built a church in Khulo, the center of Islam in upper Georgia, as well as in almost all Georgian border passages, displays the Georgian Orthodox Church's influence in Georgian cultural politics, and at the same time the churches and Christian symbols in the flags and coats of arms of Georgian districts function as territorial markers rather than as actual restrictions of minorities' religious practices. There are different discourses 
and opinions and Georgian politicians have a welcoming attitude towards the integration of minorities in the increasingly succeeding processes of nationbuilding and state-building in Georgia. However, there is a consensus among the population that Georgia, has an Orthodox Christian character and also Muslim citizens of Georgia, enjoying religious freedoms, generally subscribe to that idea. Simply there is a consensus in Georgia, particularly among the youth, that Georgia belongs to all its citizens regardless of their ethnicity and religion, yet at the same time the Orthodox Christian character of Georgia is historically built and should be respected as a national cultural heritage. This is in accordance with the legacy of the Soviet nationalities policy, by which a territory was primarily associated with the majority and was often called by the titular population's name.

In Russia Islam is regulated by the state. The actual Islamic practice differs from region to region. For example, many Dagestani and Chechen women use the Islamic headdress, whereas the Islamic headdress is less prevalent, though not absent, in the Volga region. Whereas the union republics were primarily associated with the majority titular population, Russia, as the major Soviet federative republic, was more diffused already in the Soviet era. The contemporary Russian Federation represents itself as a multicultural nation, and the minority cultures are incorporated to a significant extent in its cultural politics and nation-building process. Russian cultural politics allow ethnoreligious markers and symbols in parts of the country that are populated by minorities, especially in ethnic autonomous regions.

It appears that the rationales and legacies of the Soviet nationalities policy and its manifestations in a hierarchical territorial federalism are still prevalent and reflected in the representations of immaterial culture and symbols of peoples that are associated politically with an administrative territory. We can also reach a cautious conclusion that such representation is itself of a hierarchical nature. Whereas the political symbols depicted in flags and coats of arms at the level of Soviet successor states - the former Soviet Union republics - are clearly and strongly associated with the ethnic majority of the republics, those at the lower-level territorial units are also associated - though less strongly with the culture of minority ethnic groups that are, nevertheless, a majority in those regions. The symbols represented at the district levels, however, do not show a strong association with the culture of the majority of the inhabitants of those territories. The prevalence of usage of names and vernacular languages do not show a strong correlation with the territorial-administrative realities. Paradoxically, it appears that the Christian post-Soviet states are generally more tolerant towards the practice of certain Islamic traditions and rituals than the post-Soviet Muslims states are. A hypothetical explanation could be that the former states are less concerned about the consequences of Islamic religious practice and activism, as Muslims in these states, in contrast to the latter, constitute a minority of the population. However, in order to understand the situation better, more research is needed. 
In addition to traditional onomastic and vexillological methods of research, more ethnographic field research is needed in order to understand the meaning behind, and the reasons of, choosing certain names and symbols. Prospective research should also examine whether there is a discrepancy between different social and socioeconomic layers with regard to the preferred ethnic or religious symbols. It would also be interesting to examine whether gender or age affect the choice, popularity and preference of certain ethnic and religious markers and symbols.

Babak Rezvani received a PhD degree in 2013 from University of Amsterdam. He has delivered lectures taught several courses in the Netherlands and abroad (for example in Georgia, Armenia, Kyrgyzstan, Bulgaria, Uzbekistan, Turkmenistan, and the USA). He has taught about political and cultural geography, ethno-religious conflict and coexistence, and methods of social research. His geographic focus is on the Middle East, the Post-Soviet countries and indigenous peoples in those regions and in other parts of the world. He is currently the chairman of Association for the Study of EthnoGeoPolitics, in Amsterdam the Netherlands. That association intends to develop the field of EthnoGeoPolitics by advocating for a (re-)integration of culture into geopolitics and studying the interrelations between ethnicity (broadely understood), geography and politics.

\section{Notes}

1. Although humanities undeniably has a longer tradition in studying onomastics, social sciences, particularly human geography and anthropology, are also relevant to onomastics. Onomastics may also study place names, or toponyms, and both human geography and anthropology have a tradition of exploring places, peoples and their cultural attributes.

2. This is a follow-up to my earlier postdoctoral project about representations and imaginations of symbols among the majority and minorities in post-conflict Georgia. The studies by Peter J.M. Nas (2011) and his associates served as an inspiration. In that project, initially the same mental map approach was taken. However, the study of the meaning of symbols was extended from urban symbols to regional, ethnic and national ones as well, and more abstract types of symbolism embedded in flags and coats of arm were also taken into consideration. A part of this project about the rituals of and the symbolic meanings of death and cemeteries among the Christians and Muslims of Georgia was partially commissioned by the German Friedrich Ebertstiftung, the results of which were presented during a conference on 29 October 2016 in Münster, Germany, a more concise version of which has yet to be published. The conference was entitled 
'When the Cemetery Becomes Political: Dealing with the Religious Heritage in Multi-ethnic Regions - Cyprus, Lebanon and the Balkans', Münster, Germany, 28-29 October 2016. It was organised by the Institute for Interdisciplinary Cypriot Studies of the University of Münster (Germany) and the FriedrichEbert-Stiftung (Cyprus Office). Therefore, I want to express my gratitude and appreciations to Friedrich Ebertstiftung and my geography students at the Ivane Javakhishvili Tbilisi State University for their efforts in fieldwork and interviews. I would also like to thank Professor Edwin Lawson, a renowned authority in the field of onomastics for having introduced the field of onomastics to me and having guided me in my studies.

3. Hopefully, I will write more about this project at a later date. I will then update and more elaborately discuss my conclusions. I will also review (more recent) relevant sources, embed the discussion in a solid theoretical framework and depict figures (flags and maps) that could be useful and illustrative.

4. See particularly the aforementioned chapters in Hough and Izdebska (2016).

5. See Waynakh Online (website), 'Chechen Culture' section, including 'Chechen Men Names' and 'Chechen Women Names', http://www.waynakh.com/eng/ category/chechen-culture/page/2/ (accessed 30 September 2018); Circassian Association of California: Adyghe Khasa, 'Circassians Names', http://cakhasa. com/news/circassians_names_idx.html (accessed 30 September 2018); This Is the Caucasus, 'Names, Languages, and Cultures of the Caucasus', https:// thisisthecaucasus.wordpress.com/chechen/ (accessed 30 September 2018).

6. I hope that this article will serve as a plea for more elaborate works in the future. For discussions about the policies of Russia and other Post-Soviet countries towards religion and culture as well as about inter- and intra-religious dialogue, see e.g. Abazov 2007; Merati 2017; Ten Dam 2010; Ten Dam 2011; Ten Dam 2012; Thibault 2018; Rezvani 2019b; Rezvani 2019c.

7. I would like to thank Dr Marat Ilyasov and Professor John Colarusso, experts on the North Caucasus, for assisting me in this ongoing project.

8. There are other definitions that could be useful. For example, an Islamic toponym could be also one that is named after a person important in Islam. However, systematically investigating such toponyms are not in the scope of this current article, although I hope to discuss them in later articles.

9. However, vernacular designations may differ from the official toponyms. For example, the Zazaki-speaking inhabitants of Tunceli, in Turkey, still call it by its older name, Dersim. This reveals the necessity of familiarity with the area one studies and importance of ethnographic field research.

10. There is a certain imbalance in the collected data, as the amount and quality of secondary data about different subjects of study were not equal. Therefore, more ethnographic field studies could contribute greatly to this study.

11. In the Post-Soviet space there is another significant Shia community other than those ones in the epublic of Azerbaijan and the southern part of Dagestan in the Russian Federation. Muslims of the Gorno-Badakhshan autonomous region in Tajikistan, called Pamiris, are predominantly Ismaili Shias.

12. The authors have a good command of Turkic, Arabic and Persian and offer correct and qualitatively good translations. As far as my linguistic skills and knowledge may help their translations are generally correct and accurate. 
13. It is clear that the authors were aware of this fact, because despite the fact that the Tatar language has used Persian words in their northern or eastern phonological fashion - sometimes believed to be more archaic - the authors spell the Persian words according to their modern Persian pronunciation. For example, whenever $\mathrm{gul}$ is found in a Tatar word, it is attributed to modern Persian gol, and not to $\mathrm{gul}$ or gül. The same preference for the modern Persian pronunciation is present in the English as well as in the Russian text of the etymological dictionaries.

14. The rather popular Georgian name Teimuraz should not be confused with Temuri (from Timur, also spelled Teimur). Teimuraz is, in fact, the equivalent of the Persian name Tahmures, a figure from the Shahnameh epic poem.

15. As similar motives are also prevalent among other peoples, I reached similar preliminary conclusions based on the aforementioned hypothetical assumption. It was confirmed explicitly by several key informants in the field.

16. Iranian anthroponyms in southern Central Asia and the Republic of Azerbaijan are predominantly of new Iranian origins, as well as pre-Islamic names based on the Shahnameh epic by the poet Ferdowsi. Iranian names in Armenia are predominantly of Parthian origin. Iranian anthroponyms in Georgia are also usually based on the Shahnameh, in addition to those of Parthian origin.

17. Nevertheless, similar to the South Caucasus, there are Iranian toponyms in the North Caucasus. A prominent example is Derbent (Darband) in Dagestan. Nevertheless, these toponyms may not necessarily be qualified as Islamic.

18. As relatively more Muslims live in the larger Volga region, and hence the chances are more likely to find settlements with Islamic themes, there is more research needed in that region, and generally in the more central regions of Russia.

19. All flags are depicted in the following websites: Flags of the World, https://www. crwflags.com/fotw/flags/ (accessed 20 August 2018); Russian Centre of Vexillology and Heraldry, http://www.vexillographia.ru/ (accessed 20 August 2018).

20. However, the Russian name of Volga may have older roots and is probably borrowed from Scythian, an extinct East Iranian language that was spoken in that region in ancient times.

21. The districts in Georgia, similar to those elsewhere in the former Soviet Union, were called raion or rayon. The newer designation, however, is municipality. Nevertheless, the districts within Tbilisi are still called raions. Raion still prevails in colloquial language use among people as well.

22. The separatist regions of Abkhazia and South Ossetia also have flags. However, Georgian authorities have lost control over these regions, and their policies do not affect them directly.

23. Asking the locals about the religious composition of Kobuleti and Batumi, the locals often answer that the half (nakhevari in Georgian) are Muslims and half Christians. However, this does not necessarily mean that the population is evenly divided, as they simply may mean that the religious affiliation of the population is not totally homogenous. Kobuleti, in the northern part of Adjara, has probably had a Christian majority longer than other towns. 


\section{References}

Abazov, R. (2007), Culture and Customs of the Central Asian Republics. Westport, CT: Greenwood Publishing Group.

Ainiala, T. (2016), 'Names in Society', in The Oxford Handbook of Names and Naming, (ed.) C. Hough and D. Izdebska, (Oxford: Oxford University Press), 371-381.

Aldrin, E. (2016), 'Names and Identity', in Hough and Izdebska 2013, The Oxford Handbook of Names and Naming, 382-394.

Bassin, M. (2009), 'The Emergence of Ethno-geopolitics in Post-Soviet Russia. Eurasian Geography and Economics 50 (2): 131-149.

Berg, L.D. and J. Vuolteenaho (eds.) (2009), Critical Toponymies: The Contested Politics of Place Naming. Farnham, UK: Ashgate Publishing.

Bramwell, E.S. (2016), 'Personal Names and Anthropology', in Hough and Izdebska, The Oxford Handbook of Names and Naming, 263-278.

Gammeltoft, P. (2016). 'Names and Geography', in Hough and Izdebska, The Oxford Handbook of Names and Naming, 502-513.

Gogsadze, G. (2019), 'A Brief review on Rezvani’s EthnoGeoPolitics and Its Developments', Forum of Ethnogeopolitics 7 (1): 39-40.

Heucke, C. (2006). 'Anthropogeographie', in Der Neue Pauly, (ed.) H. Cancik, H. Schneider (Antike) and M. Landfester, (Munich: Rezeptions- und Wissenschaftsgeschichte), http://dx.doi.org/10.1163/1574-9347_dnp_e123660.

Hough, C. and D. Izdebska (eds). (2016), The Oxford Handbook of Names and Naming. Oxford: Oxford University Press.

Ilyasov, M. (2018), Этногеополитика наука или новая идеология? [Ethnogeopolitika nauka ili novaya ideologiya? (Russian); Ethnogeopolitics: A science or a new ideology?], Forum of EthnoGeoPolitics 6 (2): 12-13.

Kapplan, J. (2019), 'Ethnogeopolitics: Scholarly Fashion or Emerging Discipline?', Forum of Ethnogeopolitics 7 (2): 169-179.

Koopman, A. (2016), 'Ethnonyms', in Hough and Izdebska, The Oxford Handbook of Names and Naming, 251-262.

Lawson, E., Zavyalova, Z. and Sheil, R. (2014), Tatar First Names from West Siberia: An English and Russian Dictionary. Fredonia: State University of New York.

Martin, T. (2001). The Affirmative Action Empire: Nations and Nationalism in the Soviet Union, 1923-1939. Ithaca, NY \& London: Cornell University Press.

Merati, S.E. (2017), Muslims in Putin's Russia: Discourse on Identity, Politics, and Security. Cham, Switzerland: Springer.

Muhr, K. (2016), 'Place-Names and Religion: A Study of Early Christian Ireland', in Hough and Izdebska, The Oxford Handbook of Names and Naming, 385-602.

Nalbandov, R. (2016), Not by Bread Alone: Russian Foreign Policy Under Putin. Lincoln: University of Nebraska Press.

Nas, P.J.M. (ed.) (2011), Cities Full of Symbols: A Theory of Urban Space and Culture. Leiden: Leiden University Press.

Penck, A. (1912), Anthropogeographie: Die geographische Verbreitung des Menschen von Friedrich Ratzel, (ed.) Albrecht Penck, (Stuttgart: J. Engelhorns Nachf).

Rezvani, B. (2013b), 'EthnoGeoPolitics and Its Forum'. Forum of Ethnogeopolitics 1 (1): 4-6. 
Rezvani, B. (2015), Conflict and Peace in Central Eurasia: Towards Explanations and Understandings. Boston: Brill.

Rezvani, B. (2019a), 'EthnoGeoPolitics and Its Developments', Forum of Ethnogeopolitics 7 (1): 22-36.

Rezvani, B. (2019b), 'Political Stability, Transition and Conflict: Tajikistan Compared with Georgia', Middle Eastern Studies 55 (1): 141-156.

Rezvani, B. (2019c), 'Russian Interventions in the Post-Soviet and Syrian Conflicts', Terrorism and Political Violence 31 (6): 1376-1380.

Rezvani, B. and Gonzales, D. (2018), 'EtnoGeoPolitica y su fórum' [EthnoGeoPolitics and its forum], Forum of Ethnogeopolitics 6 (2): 8-10.

Rezvani, B. and Ilyasov, M. (2017), Этногеополитика и Форум Этногеополитики [Etnogeopolitika i forum etnogeopolitiki = EthnoGeoPolitics and forum of EthnoGeopolitics, Forum of Ethnogeopolitics 5 (2): 7-8.

Shahshahani, S. (2019), 'Integrating Culture in Political and Social Sciences', Forum of Ethnogeopolitics 7 (1): 37-38.

Shoeibi, M. (2019), ديالكتيك زئويوليتيك سنتى و زئويوليتيك انتقادى :Dialektik-e zheopolitike sonnati va zheopolitik-e enteghadi (Persian); Dialectics between classical and critical geopolitics]. Forum of Ethnogeopolitics 7 (1): 19-21.

Slezkine, Y. (1994), 'The USSR as a Communal Apartment, or How a Socialist State Promoted Ethnic Particularism', Slavic Review 53 (2): 414-452.

Suny, R. G. (1998), The Soviet Experiment: Russia, the USSR, and the Successor States. Oxford: Oxford University Press.

Ten Dam, C. (2010), 'How to Feud and Rebel: 1. Violence-values among the Chechens and Albanians', Iran and the Caucasus 14 (2): 331-365.

Ten Dam, C. (2011), 'How to Feud and Rebel: 2. Histories, Cultures and Grievances of the Chechens and Albanians', Iran and the Caucasus 15 (1-2): 235-273.

Ten Dam, C. (2012). 'How to Feud and Rebel: 3. Combat-stress and Violence-values among the Chechens and Albanians', Iran and the Caucasus 16 (2): 225-245.

Thibault, H. (2018), Transforming Tajikistan: State-building and Islam in Post-Soviet Central Asia. London: I. B. Tauris.

Zwawi, S.M. (1998), African Muslim Names: Images and Identities. Trenton, NJ: Africa World Press. 